\title{
The marine turtles of Belize
}

Don Moll

When the author visited Belize in 1983 and 1984 to survey the turtle fauna of that country, to which the Oryx $100 \%$ Fund contributed

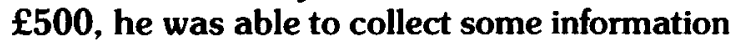
on the three marine turtle species that nest on Belize's beaches and forage along the coast. All three species are exploited in the country and, although there is a degree of legal protection, the ban on egg-collecting is widely ignored, turtles are taken for their meat in the closed season, and tortoise-shell jewellery and curios still find a ready market among tourists from abroad.

During June and July 1983, and from January until April 1984, I travelled throughout Belize (formerly British Honduras) to ascertain the status, distribution, and level of exploitation of the Belizean turtle fauna. While I spent proportionately more time in surveys of freshwater species (principally Dermatemys mawei), I was also able to collect some information concerning the resident marine species. Since all marine turtles are considered endangered or vulnerable (Groombridge, 1982), and since there is very little published information specifically concerning marine turtles in Belizean waters (see Bacon et al., 1983; Perkins, 1983), the relevant information collected is summarised here. Sources of information include foot, boat, and aerial surveys of nesting sites, and of adult and developmental foraging habitat along the entire length of the Belizean coast, as well as interviews with turtleand fin-fishermen, vendors of turtle meat, tortoise-shell and other products, and government officials involved in marine turtle protection.

\section{Nesting habitat}

The loggerhead Caretta caretta, the green turtle Chelonia mydas, and the hawksbill Eretmochelys imbricata nest in Belize, but I found no evidence of nesting concentrations anywhere. Most nests encountered are solitary, with a few encountered in groups of two, and most of the 22 nests located were on beaches of the offshore cays of the barrier reef rather than on the mainland (Table 1). Much of the mainland coast is low mangrove swamp unsuitable for nesting, and apparently suitable nesting beaches spottily distributed along the central and southern coastline were little used during the aerial surveys of these areas (1-7 July, 1983). Loggerheads and greens (two of each) were observed nesting on Placencia Peninsula; resident fishermen said that these species nest along sparsely inhabited sections of the peninsula throughout the summer. Nests on the cays were mainly observed on the central and southern reef sections scattered through the more remote, uninhabited or thinly settled cays. Only a few loggerhead nests were observed on the cays north of Dangriga; these are generally more accessible from coastal human population centres, and tend to be more populated than the lower cays. I was informed by residents of San Pedro, Ambergris Cay that all three species (but predominantly loggerheads) still occasionally nest along the north-eastern coast of Ambergris Cay, beginning about $24 \mathrm{~km}$ north of San Pedro. While the loggerhead and green nests located were widely scattered along the reef, five of eight hawksbill nests encountered were in the Sapodilla Cays of extreme southern Belize, also considered by Carr et al. (1982) as the site of 
moderate hawksbill nesting (i.e. Nicolas and other smaller cays in the area). Residents of the Sapodilla Cays informed me that more hawksbills would nest here in August and September.

\section{Turtle foraging habitat}

As cited by Carr et al. (1982), the Belize barrier reef network extends the length of the country and provides a vast area of foraging habitat for young and adult sea turtles. Younger loggerheads, greens and hawksbills from approximately 'dinner plate' to 'washtub' size were moderately common in the central and southern reef sections, and young hawksbills are encountered along the reef near Ambergris Cay in northern Belize where they are seen by divers and occasionally caught in fish weirs. While they may be encountered anywhere, adults of all three species were also more commonly observed along the lower reef network. Adult loggerheads were usually observed within the reef or occasionally in deep water outside the reef, while both adult and juvenile hawksbills were most often seen near the reef itself. Young loggerheads and greens, and adult green turtles, were often observed in shallow waters nearer the shore than the other species-age groups, where vast beds of turtle grass provide excellent foraging habitat. Although leatherbacks Dermochelys coriacea may travel through Belizean waters (Carr et al., 1982), I saw none in these surveys.

\section{Exploitation of sea turtles in Belize}

All three species are caught and used for private consumption or sold commercially in Belize. The meat of green turtles (locally called 'white turtle' in the market) is most prized and is seasonally available in coastal markets and restaurants in Belize. The meat of loggerheads is considered inferior and is not sold as often, but is privately eaten on Ambergris Cay and presumably elsewhere in Belize. I observed four loggerheads that were caught outside the reef at Ambergris Cay during March, 1984 and had been brought into San Pedro to be butchered. Also, the remains of butchered loggerheads are occasionally encountered along the beaches.

Hawksbills are not usually eaten, but are killed 156
Table 1. Locations of marine turtle nests observed in Belize during air, boat and foot surveys conducted during June and July, 1983

\begin{tabular}{|c|c|c|c|}
\hline Species & Nest location & Number & $\begin{array}{l}\text { Survey } \\
\text { method }\end{array}$ \\
\hline Caretta caretta & $\begin{array}{l}\text { Ambergris Cay } \\
\text { (Rocky Point) } \\
\text { Long Cay, } \\
\text { Lighthouse Reef } \\
\text { Northem Cay, } \\
\text { Lighthouse Reef } \\
\text { Carrie Bow Cay } \\
\text { South Water Cay } \\
\text { Placencia Peninsula } \\
\text { (lower) } \\
\text { Ranguana Cay }\end{array}$ & $\begin{array}{l}1 \\
1 \\
1 \\
1 \\
\\
2 \\
1\end{array}$ & $\begin{array}{l}\text { Air } \\
\text { Air } \\
\text { Air } \\
\text { Boat } \\
\text { Boat } \\
\text { Foot } \\
\text { Air }\end{array}$ \\
\hline Chelonia mydas & $\begin{array}{l}\text { Placencia Peninsula } \\
\text { (lower) } \\
\text { Pompion Cay } \\
\text { South Silk Cay } \\
\text { Northeast Cay } \\
\text { (Sapodilla Group) }\end{array}$ & $\begin{array}{l}2 \\
1 \\
1 \\
1\end{array}$ & $\begin{array}{l}\text { Foot } \\
\text { Air } \\
\text { Air } \\
\text { Air }\end{array}$ \\
\hline $\begin{array}{l}\text { Eretmochelys } \\
\text { imbricata }\end{array}$ & $\begin{array}{l}\text { Ranguana Cay } \\
\text { Pompion Cay } \\
\text { Southwest Cay, } \\
\text { Glover's Reef } \\
\text { Nicolas Cay } \\
\text { (Sapodilla Group) } \\
\text { Hunting Cay } \\
\text { (Sapodilla Group) } \\
\text { Lime Cay } \\
\text { (Sapodilla Group) }\end{array}$ & $\begin{array}{l}1 \\
1 \\
1 \\
2 \\
2 \\
1\end{array}$ & $\begin{array}{l}\text { Air } \\
\text { Air } \\
\text { Air } \\
\text { Air } \\
\text { Air } \\
\text { Air }\end{array}$ \\
\hline
\end{tabular}

and sold for their shells, from which tortoise-shell jewellery and curios are made. Despite a ban on the taking of juveniles, beautifully patterned young specimens are stuffed and sold as wall decorations. A sizeable population of locally collected hawksbills decorate the town of San Pedro, since almost every shop and hotel has several adorning their walls. American tourists are the main purchasers of tortoise-shell products here; they are either unaware or unconcerned that sea-turtle products may not be legally imported into the USA (there is no law against selling the products in Belize, however). When I reminded purchasers that this was the case and explained the reasons for the ban, I was usually passed off as a crank or ignored completely. A Placencia Fishermen's Co-operative exported many hawksbill shells to France in the mid-1970s

Oryx Vol 19 No 3 


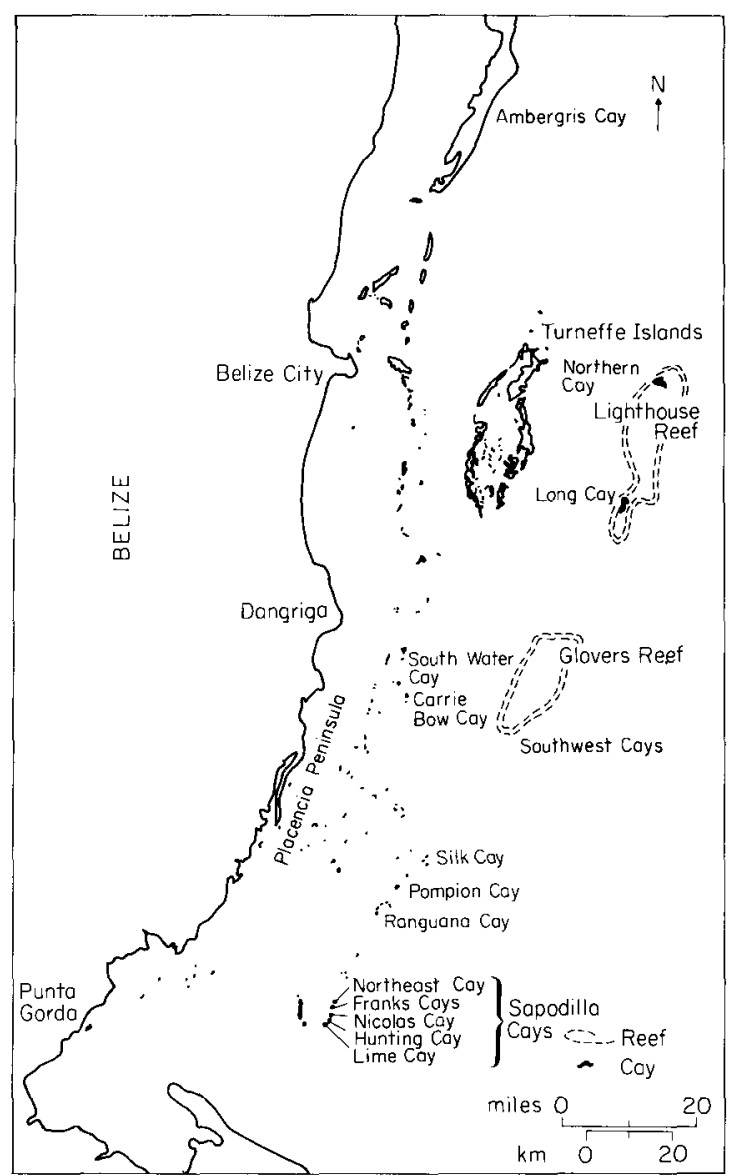

before export of sea-turtle products became illegal in 1977. According to Mr G. Winston Miller, Fisheries Unit Laboratory Administrator, this trade caused a noticeable decline in the Belizean hawksbill population.

Eggs may not be legally harvested in Belize, but the ban is widely ignored. Eggs of all three species are gathered whenever possible and used privately or sold. In 1982, Honduran and Guatemalan citizens paid US $\$ 1.00$ per dozen for seaturtle eggs gathered at Placencia and smuggled across their respective borders for sale (G. W. Miller, pers. comm.).
Laws protect all marine turtles and their eggs from June until August, and greens and hawksbills under 50 pounds (approximately $23 \mathrm{~kg}$ ) and loggerheads under 30 pounds (approximately $13.5 \mathrm{~kg}$ ) are protected. Enforcement of laws is difficult, however, due to the lack of manpower and boats swift enough to overtake poachers, and the extensive areas that must be patrolled. Sea turtles taken during the close season are not openly marketed, but are butchered and the meat sold in small packages door to door (G. W. Miller, pers. comm.).

One commercial turtle fisherman from Mullins River (central Belize near Dangriga) catches four to five turtles (mainly greens) per week during the legal season by setting nets near rock piles in the turtle grass beds near shore.

\section{Acknowledgments}

I wish to thank the Belize Government, particularly Mr G. Winston Miller, Fisheries Administrator of the Fisheries Unit Laboratory, for permission to conduct these surveys, and for generously providing information concerning marine turtles in Belize. The Reverend Leonard E. Deickman, S.J. of Saint John's College, Belize City, provided his extensive knowledge of Belize and arranged for me to meet many helpful contacts during my stay. Funding for turtle surveys in Belize was provided by the Southwest Missouri State University (SMSU) Faculty Research Fund, the SMSU Foundation, the FFPS and the World Wildlife Fund-US

\section{References}

Bacon, P., Berry, F., Bjorndal, K., Hirth, H., Ogren, L. and Weber, M. 1983. Proceedings of the Westem Atlantic Turtle Symposium, Vol. 2. University of Miami Press, Miami.

Carr, A., Meylan, A., Mortimer, J., Bjorndal, K. and Carr, T. 1982. Surveys of Sea Turtle Populations and Habitats in the Westem Atlantic. NOAA Technical Memorandum NMFS-SEFC-91, Panama City, Florida.

Groombridge, B. The IUCN Amphibia-Reptilia Red Data Book, Part 1. Testudines, Crocodylia, Rhynchocephalia. IUCN. Gland (Morges, Switzerland).

Perkins, J.S. 1983. The Belize Bamier Reef Ecosystem: An Assessment of its Resources, Conservation, Status and Management. Report sponsored by the New York Zoological Society, New York.

Don Moll, Biology Department, Southwest Missouri State University, Springfield, Missouri 65804, USA. 